\title{
The Effects of Overeating, Socioeconomic Status and Modern Practices: A Structural Equation Modelling Approach to Obesity in Teenage Girls
}

${\text { Priyanka } \text { Victor }^{*} \text { and Preethi Victor }}^{2}$

${ }^{1}$ Assistant Professor, Dept. of Mathematics, Auxilium College (Autonomous), Vellore 632007

${ }^{2}$ Assistant Professor, Dept. of Mathematics, Jyothi Nivas College, Bangalore, Karnataka-560095

\begin{abstract}
This study investigates the effects and the relationship between the factors that cause childhood obesity. Several practices such as increased consumption of sweetened drinks, fast foods, eating while watching television (TV), skipping breakfast, reduced family meal times and lower consumption of healthy foods accelerate the rate of childhood obesity. Media plays a major role in the lives of millennials. Recent studies have established that there is an increase in obesity rates in low socioeconomic groups which indicates that it is an important factor to be considered while developing the model. Structural equation modelling (SEM) is a quantitative model approach which brings out the relationships between various factors. Exploratory factor analysis is used to examine the SEM model. The latent variables are over eating, socio economic status and modern practices. The observed variables are family income, educational qualification of parents, physical activities, stress, BMI, food practices, consumption of junk food, consumption of vegetables and media availability. The sample consists of school and college students $(n=250)$ in Vellore-Tamil Nadu between the ages 13-18. The data collection was conducted through Questionnaires. SPSS (Statistics \& Amos) software is used for SEM modelling. The proposed model is found to be an acceptable fit.
\end{abstract}

Key words:Childhood Obesity, Structural equation modelling, Exploratory factor analysis, Multi variate statistical analysis

AMS classification:

1* priyankavictor2@gmail.com, ${ }^{2}$ preethivictor2@gmail.com Page 125 of 136 
ISSN: 2456-8686, Volume 4, Issue 1, 2020:125-136

DOI : http://doi.org/10.26524/cm72

\section{Introduction}

Obesity is a pathology that has a multifactor etiology. Genetics and environment interact and play various roles in different socioeconomic realities, establishing a disease with high prevalence in industrialized countries and in developing countries where a process of westernization is occurring. In the case of a child at risk of becoming overweight (including dietary, physical aspects, and sedentary behavior), the main characteristics can be explained by the influence of family and school environment as well as a larger social environment [30]. According to CDC, Childhood obesity is a serious problem in the United States putting children and adolescents at risk for poor health. Obesity prevalence among children and adolescents is still too high. For children and adolescents aged 2-19 years:

- The prevalence of obesity was 18.5 percentage and affected about 13.7 million children and adolescents.

- Obesity prevalence was 13.9 percentage among 2- to 5-year-olds, 18.4 percentage among 6- to 11-year-olds, and 20.6percentage among 12- to 19-year-olds. Childhood obesity is also more common among certain populations.

India has the second highest number of obese children in the world, with 14.4 million reported cases, according to a new study published in The New England Journal of Medicine.

Low L. C. (2010) and Harish Ranjani et.al (2016) studied the obesity prevalence among children and its effects. Obesity is prevalent among all age groups. Childhood obesity mostly often leads to obesity in adulthood. Childhood obesity causes hypertension, non-alcoholic liver disease, insulin resistance, dyslipidaemia, pulmonary disorders and psychological problems. Sanjay Kalra et al. (2012), Seema Gulati et al. (2014) and Ranjit M Anjana et al. (2014) analysed the obesity epidemic in India and the underlying causes leading to the rapid increase in obesity. According to the National Family Health Survey (NFHS), the obesity among married women is increasing and a large percentage of people in India are inactive and very few engage in recreational physical activity.

Eric A. Finkelstein et al and Claire Wang et al (2007) forecasted the obesity conditions. The study estimates a 33 percentage increase in obesity prevalence and a 130 percentage increase in severe obesity prevalence over the next 2 decades. If these forecasts prove accurate, this will further hinder efforts for healthcare cost containment. As the baby boom generation approaches retirement age, the continuing obesity epidemic signals a likely expansion in the population with obesity-related comorbidities.

${ }^{1 *}$ priyankavictor2@gmail.com, ${ }^{2}$ preethivictor2@gmail.com

Page 126 of 136 
Works have been carried out in the structural equation modelling of obesity by Diane T. Finegood et al(2010), Rita Orji et al (2012) . The Foresight obesity system map takes into account the complexity of and interrelationships between the variables and determinants of obesity and suggests possible intervention points. Development of the Foresight map helps in understanding the complexity of the obesity. Complex problems such as obesity demand appropriate tools in identification of core problem.

Muskaan Gumani et al., W. Douglas Evans et al. (2010), W. Douglas Evans et al.(2005), Janet D. Latner et al (2007) examined the consequences of recent practices that lead the way to obesity. Modern practices like increased consumption of sweetened drinks, fast foods, eating while watching television (TV), skipping breakfast, reduced family meal times eating together, and lower consumption of healthy foods have all been associated with increased rates of childhood obesity. Media has a major role in the lives of millenials. The constant exposure to media encourages children to many unhealthy habits such as smoking and consumption of junk foods. Researchers have established that there is an association between heavy television viewing and frequent snacking of sugary beverages and frequent visits to fast-food chains. Heavy television viewing is also negatively associated with the consumption of fruits and vegetables. Availability of fast foods at a high rate near and in colleges and schools also should be noted. Media exposure is significantly associated with obesity stigma.

Several authors have worked on SEM models including various factors, Binge Eating and Exercise Behavior after Surgery for Severe Obesity by Junilla K. Larsen et al(2006), Associations among overeating, overweight, and attention deficit/ hyperactivity disorder by Caroline Davis et al. (2006), the relations between sensitivity to reward and overeating were analysed and confirmed by Caroline Davis et al (2007). Various researches have been conducted regarding childhood obesity. The role of family environment in childhood obesity by Hui Huang et al. (2017), the role of maternal feeding strategies and child food intake by Katja Kröller and Petra Warschburger (2009), the relation between body weight and depression among children by M Chaiton et al (2017) and Alina Dragan and Noori Akhtar-Danesh (2007).

\section{Materials and Methods}

\section{Socioeconomic Status}

The latent variable socioeconomic status consists of three indicators namely age of the parents, Work experience of parents and Educational qualification of parents. The 


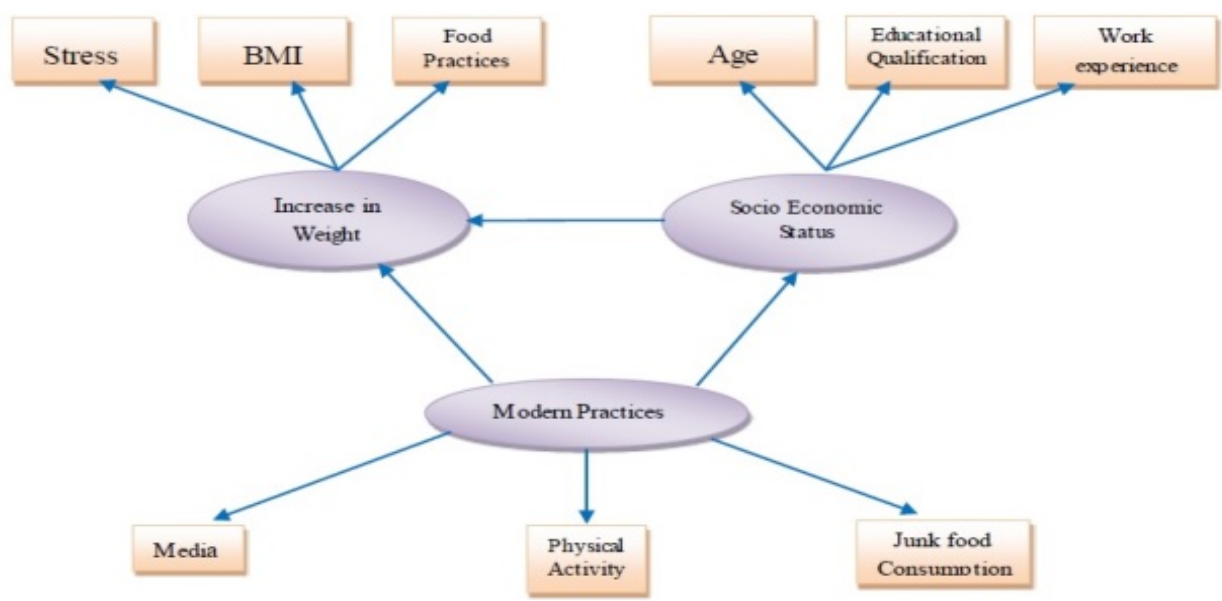

Figure 1: Research Framework

parents age were classified into four groups: 30 years or younger, 30-40 years, 40-50 years, above 50 years. The education qualification of the parents were categorised into four groups: Less than high school, high school, Diploma or Bachelor degree, Masters degree or Ph.D.

\section{Modern practices}

The indicators of modern practices are consumption of junk food, physical activity and media availability. We measured the child's fast food intake based on Kröller and Warschburger study. Parents indicated on a six-point scale ("never", "rarely", "sometimes", "usually", "always" and "several times a day") how often their children eat junk foods. Physical activity was divided into five categories: None, 1-2 times per week, 3-4 times per week, 5-6 times per week, Everyday. We use a five pointer scale for Media availability from less than one hour per day to more than four hours per day.

\section{Over eating}

Height, weight and food consumption are the observed variables of over eating. Weight of the child is divided into 7 categories: $5-10 \mathrm{~kg}, 10-20 \mathrm{~kg}, 20-30 \mathrm{~kg}, 30-40 \mathrm{~kg}$, $40-50 \mathrm{~kg}, 50-60 \mathrm{~kg}$ and $¿ 60 \mathrm{~kg}$. The height of the child is divided into four categories: ¡50 cms, 50-100 cms, 100-150 cms and ¿150 cms. We measured the child's food intake based on Kröller and Warschburger study. Parents indicated on a six-point scale ("never", "rarely", "sometimes", "usually", "always" and "several times a day") 
how often their children eat food.

\section{Sampling}

In the present study, we have considered two groups. The first group consists of teenage girls aged from 13 to 15, the second group consists of teenage girls aged from 16-18. We distributed 250 questionaires to random household with teenage girls in Vellore, Tamil Nadu and asked them to fill out the questionnaires. The regions that we covered Katpadi, Bagayam, Adukamparai, Gudiyatham and Thiruvalam. The questionnaire is given in the appendix. The first group consisted of 125 girls from the above mentioned areas who participated and responded to the questions in the questionnaire. The second group consisted of 125 girls from 16- 18 years who also participated actively. The data was collected from each person personally and the doubts were cleared in case of any. There was no incomplete questionnaires.

\section{Results}

\section{Structural Model}

Structural model of childhood obesity was constructed using the SPSS Amos software. The model shows relationship between junk food consumption and food practices and also with BMI, Health and education, education and physical activity. The dataset obtained from the questionnaire of teenage girls aged from 13 to 15 and teenage girls aged from 16-18 is incorporated in the SEM model and the confirmatory factor analysis is carried out. Few paths were incorporated to the formulated model to improve the model fit. The SEM model for group 1 and 2 is found to be having a good fit. We obtained a non-significant chi-square $\chi^{2}=33.327, \mathrm{df}=20$ and $p=0.031$ for group 1 and chi-square $\chi^{2}=44.890, \mathrm{df}=20$ and $p=0.001$ for group 2 indicating a good absolute or overall model fit.

\section{Study Reliability and Validity}

Fornell and Larcker[31] defined questionnaire validity and reliability based on the following terms and conditions:

1. Validity: Cronbach's alpha of every latent variable must be equal to or higher than 0.7

2. Reliability:

- The average variance extracted (AVE) for every latent variable must be equal to or higher than 0.50

- The factor loading of every indicator must be higher than 0.70 in the

${ }^{1 *}$ priyankavictor2@gmail.com, ${ }^{2}$ preethivictor2@gmail.com

Page 129 of 136 
ISSN: 2456-8686, Volume 4, Issue 1, 2020:125-136

DOI : http://doi.org/10.26524/cm72

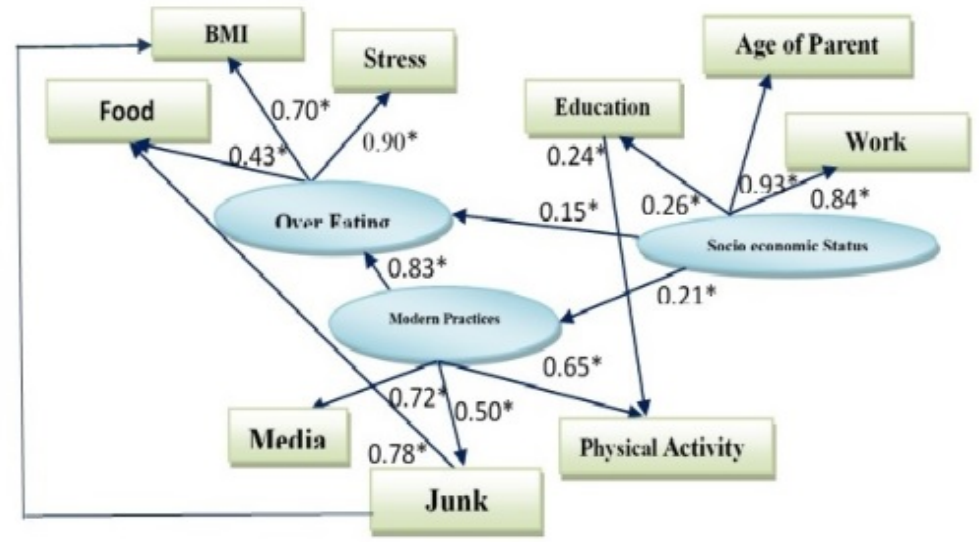

Figure 2: SEM Obesity model for group $1\left({ }^{*}-p<0.01\right)$.

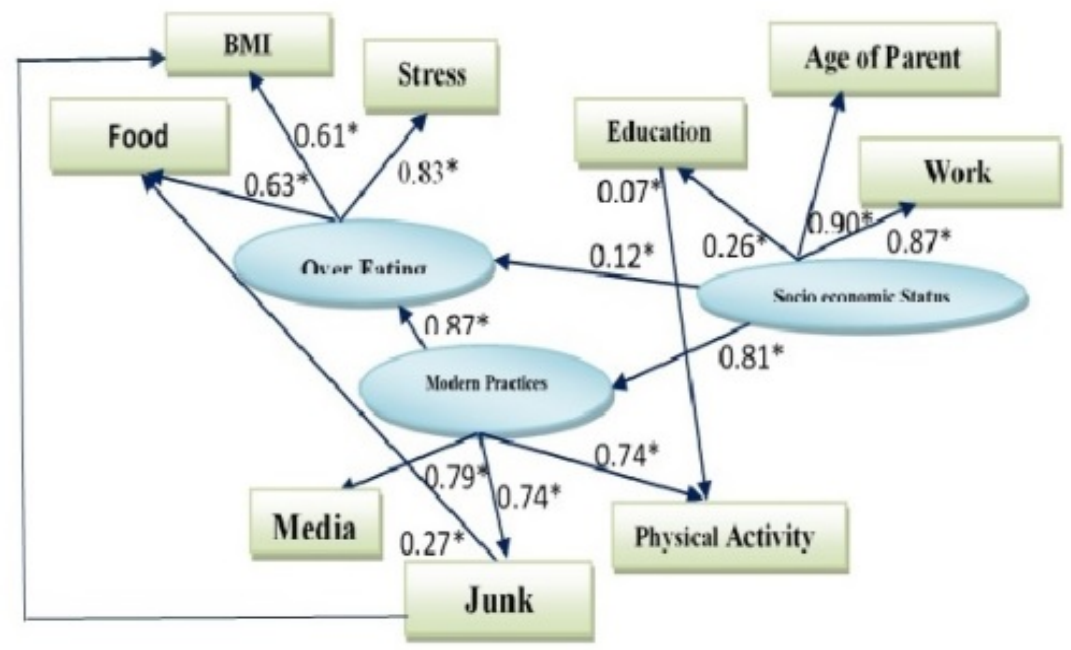

Figure 3: SEM Obesity model for group $2\left({ }^{*}-p<0.01\right)$. 
ISSN: 2456-8686, Volume 4, Issue 1, 2020:125-136

DOI : http://doi.org/10.26524/cm72

construct

Table 1 shows the outputs from the AVE and Cronbach's alpha analysis. There are three groups of indicators namely modern practices, socio economic status and over eating. Table 1 illustrates that all research group variables have acceptable Cronbach's alpha and AVE values.

\begin{tabular}{|l|l|l|l|l|}
\hline Construct & AVE for group 1 & AVE for group 2 & $\begin{array}{l}\text { Cronbach's } \\
\text { Alpha } \\
\text { for group 1 }\end{array}$ & $\begin{array}{l}\text { Cronbach's } \\
\text { Alpha for } \\
\text { group 2 }\end{array}$ \\
\hline $\begin{array}{l}\text { Modern } \\
\text { Practices }\end{array}$ & 0.689 & 0.651 & 0.729 & 0.884 \\
\hline $\begin{array}{l}\text { Socio Economic } \\
\text { Status }\end{array}$ & 0.765 & 0.855 & 0.804 & 0.790 \\
\hline Over eating & 0.60 & 0.788 & 0.776 & 0.803 \\
\hline
\end{tabular}

Table 1: AVE and Cronbach's Alpha for group 1 and 2.

The fit of the SEM model for groups 1 and 2 are checked. The Root mean square residual(RMR), Goodness of fit index(GFI), Adjusted Goodness of fit index(AGFI), Comparative fit index(CFI) and Root mean square error of Approximation(RMSEA) of the model are found to be within acceptable ranges. The model fit implies that the model is plausible.

\begin{tabular}{|c|c|c|c|}
\hline Measure & Cut-off for good fit & Model fit for group 1 & Model fit for group 2 \\
\hline RMR & $\prec 0.08$ & 0.065 & 0.074 \\
\hline GFI & $\geq 0.95$ & 0.95 & 0.951 \\
\hline AGFI & $\geq 0.90$ & 0.982 & 0.909 \\
\hline CFI & $\geq .90$ & 0.977 & 0.930 \\
\hline RMSEA & $\prec 0.08$ & 0.073 & 0.080 \\
\hline
\end{tabular}

Table 2: Model fit for SEM obesity model

Bivariate correlation coefficients among all measured variables of Group 1 and 2 are given below:

${ }^{1 *}$ priyankavictor2@gmail.com, ${ }^{2}$ preethivictor2@gmail.com

Page 131 of 136 


\begin{tabular}{|c|c|c|c|c|c|c|c|c|c|}
\hline & $\begin{array}{l}\text { Junk } \\
\text { Food }\end{array}$ & Stress & $\begin{array}{l}\text { Education } \\
\text { of Parents }\end{array}$ & $\begin{array}{l}\text { Physical } \\
\text { Activity }\end{array}$ & Food I & BMI & Medlia & $\begin{array}{l}\text { Work } \\
\text { Experience } \\
\text { of Parents }\end{array}$ & $\begin{array}{l}\text { Age of } \\
\text { Parents }\end{array}$ \\
\hline $\begin{array}{l}\text { Junk } \\
\text { Food }\end{array}$ & $\begin{array}{l}1.00 \\
0\end{array}$ & & & & & & & & \\
\hline Stress & .721 & $\begin{array}{l}1.00 \\
0\end{array}$ & & & & & & & \\
\hline $\begin{array}{l}\text { Educatio } \\
\text { n of } \\
\text { Parents }\end{array}$ & .578 & .636 & 1.000 & & & & & & \\
\hline $\begin{array}{l}\text { Physical } \\
\text { Activity }\end{array}$ & .593 & .663 & 610 & 1.000 & & & & & \\
\hline Food & 679 & .712 & .574 & .605 & $\begin{array}{l}1.00 \\
0\end{array}$ & & & & \\
\hline BMI & .592 & .583 & .630 & .487 & .617 & 1.000 & & & \\
\hline Media & .546 & .617 & .616 & .658 & .623 & .552 & 1.000 & & \\
\hline $\begin{array}{l}\text { Work } \\
\text { Experien } \\
\text { ce of } \\
\text { Parents }\end{array}$ & .470 & .583 & .711 & .542 & .535 & .593 & .556 & 1.000 & \\
\hline $\begin{array}{l}\text { Age of } \\
\text { Parents }\end{array}$ & .441 & .571 & .716 & .630 & .617 & .559 & .612 & .782 & 1.000 \\
\hline
\end{tabular}

\begin{tabular}{|c|c|c|c|c|c|c|c|c|c|}
\hline & $\begin{array}{l}\text { Junk } \\
\text { Food }\end{array}$ & Stress & $\begin{array}{l}\text { Education } \\
\text { of Parents }\end{array}$ & $\begin{array}{l}\text { Physical } \\
\text { Activity }\end{array}$ & Food & BMII & Media & $\begin{array}{l}\text { Work } \\
\text { Experience } \\
\text { of Parents }\end{array}$ & $\begin{array}{l}\text { Age of } \\
\text { Parents }\end{array}$ \\
\hline $\begin{array}{l}\text { Junk } \\
\text { Food }\end{array}$ & $\begin{array}{l}1.00 \\
0\end{array}$ & & & & & & & & \\
\hline Stress & .614 & $\begin{array}{l}1.00 \\
0\end{array}$ & & & & & & & \\
\hline $\begin{array}{l}\text { Educatio } \\
n \text { of } \\
\text { Parents }\end{array}$ & .574 & .621 & 1.000 & & & & & & \\
\hline $\begin{array}{l}\text { Physical } \\
\text { Activity }\end{array}$ & .503 & .524 & .524 & 1.000 & & & & & \\
\hline Food & .577 & .573 & .479 & .532 & $\begin{array}{l}1.00 \\
0\end{array}$ & & & & \\
\hline BMI & .592 & .583 & .630 & .487 & .617 & 1.000 & & & \\
\hline Media & .414 & .404 & .334 & .302 & .641 & .552 & 1.000 & & \\
\hline $\begin{array}{l}\text { Work } \\
\text { Experien } \\
\text { ce of } \\
\text { Parents }\end{array}$ & .439 & .591 & .522 & .490 & .609 & .479 & .556 & 1.000 & \\
\hline $\begin{array}{l}\text { Age of } \\
\text { Parents }\end{array}$ & .419 & .482 & .449 & .667 & .524 & .531 & .788 & .782 & 1.000 \\
\hline
\end{tabular}

\section{Discussion}

In both the groups, modern practices has significant impact over eating. But group $2(\beta=0.87)$ has a higher impact of modern practices on over eating compared to group $1(\beta=0.83)$. The impact of socio economic status on modern practices is higher in group $2(\beta=0.81)$ compared to group $1(\beta=0.21)$. Therefore, it is observed that there is a high chance of socio economic status of parent leading to over eating in teenage girls aged between 16-18. The present research shows a direct relation between socio economic status of parents and over eating.

\section{Appendix}

The questionnaire distributed to the children for the analysis of obesity SEM model is as follows: 
ISSN: 2456-8686, Volume 4, Issue 1, 2020:125-136

DOI : http://doi.org/10.26524/cm72

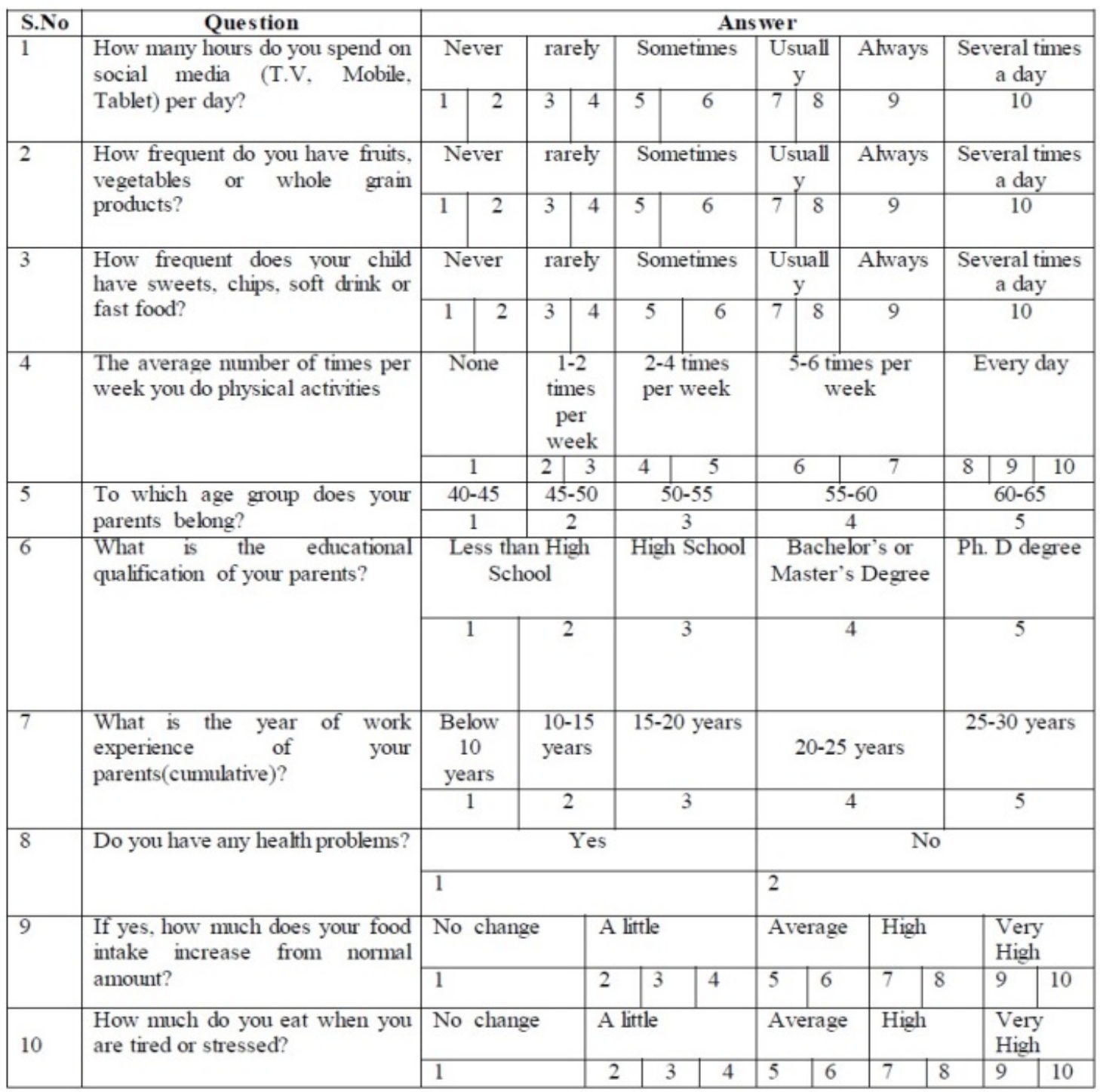

1* priyankavictor2@gmail.com,${ }^{2}$ preethivictor2@gmail.com

Page 133 of 136 
ISSN: 2456-8686, Volume 4, Issue 1, 2020:125-136

DOI : http://doi.org/10.26524/cm72

References

[1] Jichuan Wang and Xiaoqian Wang, Structural Equation Modeling: Applications using Mplus, JohnWiley \& Sons Ltd, 2012.

[2] Low, L. C, Childhood obesity in developing countries, World Journal of Pediatrics, 6(3), 2010, pp.197-199.

[3] Ananya Mukhejee, Understanding Emerging epidemics: Social and political approaches, Advances in Medical Sociology, 11.

[4] Sanjay Kalra, A. G. Unnikrishnan, Obesity in India: The weight of the nation, Journal of Medical Nutrition and Nutraceuticals, 1(1),2012.

[5] Harish Ranjani, T.S. Mehreen, Rajendra Pradeepa, Ranjit Mohan Anjana, Renu Garg ,Krishnan Anand \& Viswanathan Mohan, Epidemiology of childhood overweight \& obesity in India: A systematic review, Indian J Med Res, 143, 2016, pp. 160-174.

[6] Seema Gulati, and Anoop Misra, Sugar Intake, Obesity, and Diabetes in India, Nutrients, 6, 2014, pp.5955-5974, doi:10.3390/nu6125955.

[7] Ranjit M Anjana1, Physical activity and inactivity patterns in India - results from the ICMR-INDIAB study (Phase-1) [ICMR-INDIAB-5], International Journal of Behavioral Nutrition and Physical Activity, 11(26),2014.

[8] Eric A. Finkelstein et al, Obesity and Severe Obesity Forecasts Through 2030, Published by Elsevier Inc. on behalf of American Journal of Preventive Medicine.

[9] Y. Claire Wang, Graham A. Colditz, and Karen M. Kuntz, Forecasting the Obesity Epidemic in the Aging U.S. Population, Obesity, 15(11),2007.

[10] Diane T. Finegood, Thomas D.N. Merth and Harry Rutter, Implications of the Foresight Obesity System Map for Solutions to Childhood Obesity, Obesity, 18 (1),2010.

[11] FORESIGHT Tackling Obesities: Future Choices - Project Report Government Office for Science.

[12] Rita Orji, Regan L. Mandryk, and Julita Vassileva, Towards a Data-Driven Approach to Intervention Design: A Predictive Path Model of Healthy Eating Determinants, Persuasive, LNCS 7284,2012, pp. 203-214.

[13] Muskaan Gumani, Catherine Birken and Jill Hamilton, Childhood Obesity Causes, Consequences and Management, DOI: 10.1016/j.pcl.2015.04.001.

\footnotetext{
${ }^{1 *}$ priyankavictor2@gmail.com, ${ }^{2}$ preethivictor2@gmail.com
}

Page 134 of 136 
[14] W. Douglas Evans, Katherine K Christoffel, Jonathan W Necheles and Adam B Beckers, Social Marketing as Childhood Obesity Prevention Strategy, obesity, $18(1), 2010$.

[15] W. Douglas Evans, Eric A. Finkelstein, Douglas B. Kamerow, Jeanette M. Renaud, Public Perceptions of Childhood Obesity, American Journal of Preventive Medicine, 28(1), 2005, pp. 26-32.

[16] Janet D. Latner, Juliet K. Rosewall, Murray B. Simmonds, Childhood Obesity Stigma: Association with television, videogame and magazine exposure, Body Image, 4,2007, pp.147-155.

[17] Junilla K. Larsen, Rinie Geenen, Bert van Ramshorst, Nico Brand, Joop J. Hox, Wolfgang Stroebe, Lorenz J.P. van Doornen, Binge eating and exercise behavior after surgery for severe obesity: A structural equation model, International Journal of Eating Disorders 39(5), 2006, pp. 369-375.

[18] Caroline Davis , Robert D. Levitan, Megan Smith, Stacey Tweed, Claire Curtis, Associations among overeating, overweight and Attention deficit/hyperactivity disorder: A structural equation modelling approach, Eating Behaviors, 7, 2006, pp. 266-274.

[19] Caroline Davis, Karen Patte, Robert Levitan, Caroline Reid, Stacey Tweed, Claire Curtis, From motivation to behaviour: A model of reward sensitivity, over eating and food preferences in the risk profile for obesity, Appetite, 48,2007, pp. $12-19$.

[20] Hui Huang, Che Wan Jasimah btWan Mohamed Radzi and Hashem Salarzadeh Jenatabadi, Family Environment and Childhood obesity: A new framework for Structural equation modelling, International Journal of Environmental Research and Public Health, 14(181),2017.

[21] Katja Kröller and Petra Warschburger, Maternal feeding strategies and child food intake: Considering weight and demographic influences using Structural equation modeling, International Journal of Behavioral Nutrition and Physical Activity, 6(78),2009.

[22] M Chaiton, C Sabiston, J O’Loughlin, JJ McGrath, K Maximova, and M Lambert, A structural equation model relating adiposity, psychosocial indicators of body image and depressive symptoms among adolescents, Int J Obes (Lond), 33(5), 2017, pp. 588-596.

\footnotetext{
${ }_{1 *}$ priyankavictor2@gmail.com, ${ }^{2}$ preethivictor2@gmail.com
}

Page 135 of 136 
[23] Alina Dragan and Noori Akhtar-Danesh, Relation between body mass index and depression: A structural equation modeling approach, BMC Medical Research Methodology, 7(17),2007.

[24] Rakhi Thakur and Mala Srivastava, Adoption readiness, personalinnovativeness, perceived risk and usage intention across customer groups for mobile payment services in India, Internet Research, 24(3), 2014, pp. 369-392.

[25] Snigdha Chakrabarti \& Chaiti Sharmab Biswas, An Exploratory Analysis of Women's Empowerment in India: A Structural Equation Modelling Approach, The Journal of Development Studies, 48(1), 2012, pp. 164-180.

[26] Sudas Roy and Paromita Goswami, Structural equation modeling of value-psychographic trait-clothing purchase behavior: a study on the urban college-goers of India, 8(4), 2007, pp. 269-277.

[27] Siddhivinayak Hirve, Johan H. L. Oud, Somnath Sambhudas, Sanjay Juvekar, Yulia Blomstedt, Stephen Tollman, Stig Wall, Nawi Ng, Unpacking Self-Rated Health and Quality of Life in Older Adults and Elderly in India: A Structural Equation Modelling Approach, Soc Indic Res, DOI 10.1007/s11205-013-0334-7.

[28] Ratnadeep Mukherjee, Pijus Kanti Barman, Pravat Thatoi, Birendra Kumar Prusty, Rina Tripathy, Bidyut Kumar Das and Balachandran Ravindran, Sepsis: Partial least squares structural equation 1 modelling (PLS-SEM) suggests a critical role for anti-inflammatory responses in clinical severity, doi: http://dx.doi.org/10.1101/193615,2017.

[29] Jaya Prasad Tripathy, J S Thakur, Gursimer Jeet and Sanjay Jain, Structural equation modeling to identify the risk factors of diabetes in the adult population of North India, Tropical Medicine and Health, 46(23),2018.

[30] Debasis Bagchi, Global Perspectives on Childhood Obesity: Current Status, consequences and Prevention, Academic Press, 2011.

[31] Fornell, C.; Larcker, D.F. Evaluating structural equation models with unobservable variables and measurement error. J. Mark. Res. 18, 1981, 39-50.

\footnotetext{
${ }^{1 *}$ priyankavictor2@gmail.com, ${ }^{2}$ preethivictor2@gmail.com
}

Page 136 of 136 